\title{
Iniciação Científica
}

O Programa Institucional de Iniciação Cientifica (PIBIC) visa despertar a vocação científica e incentivar a participação de estudantes de graduação em projetos de pesquisa. Ele é um importante incentivo e uma preparação para o ingresso na pós-graduação.

Nesse sentido é que nosso PPG em Teologia tem incentivado, há anos, a participação de nossos graduandos no PIBIC. A partir desse volume, decidimos apresentar, nesta seção especial, os resumos das pesquisas apresentadas em nossos Seminários anuais de Iniciação Científica. Nesse ano de 2010, de 24 a 27 de agosto, a PUC-Rio realizou o seu XVIII Seminário.

Nas páginas seguintes, o leitor de Atualidade Teológica encontrará os resumos das pesquisas de Iniciação Científica realizadas de agosto de 2009 a junho de 2010 em nosso Programa.

Prof. Dr. Abimar Oliveira de Moraes Coordenador Departamental do PIBIC 